\title{
Differential effects of suspended sediments on larval survival and settlement of New Zealand urchins Evechinus chloroticus and abalone Haliotis iris
}

\author{
Nicole E. Phillips*, Jeffrey S. Shima \\ School of Biological Sciences, PO Box 600, Victoria University of Wellington, Wellington 6001, New Zealand
}

\begin{abstract}
Larvae of marine organisms play an important role in the dynamics of populations, are generally sensitive to environmental stressors, and vary dramatically among species in life history traits. We examined the effects of suspended sediments from terrestrial runoff on larval development, survival, and settlement of New Zealand sea urchins Evechinus chloroticus and abalone Haliotis iris. Larval urchins and abalone were reared under 5 suspended sediment regimes (variable concentrations and timing of exposure, benchmarked against nearby field conditions), and in the absence of sediments. Stage specific per capita mortality rates of urchin larvae increased with concentrations of suspended sediments, and generally, these rates (and the sensitivity of urchin larvae to sediments) decreased with age. Mortality rates of abalone similarly increased in response to sediment concentrations, although older larvae continued to incur high losses when exposed to sediments. Mortality rates of both abalone and urchins increased in response to acute exposure to sediments early in development. For urchins, this effect was immediate and coincident only with exposure to sediments, whereas elevated mortality rates persisted well after the removal of sediments for abalone. Cumulative survival to competency was similar among species and generally decreased with exposure time and/or concentration of sediments. Urchins were twice as likely to settle and metamorphose as abalone but patterns were not related to larval sediment regime for either species. The strong species specific responses to suspended sediments we observe may greatly alter patterns of larval connectivity in marine meta-communities.
\end{abstract}

KEY WORDS: Suspended sediment $\cdot$ Runoff $\cdot$ Larval mortality $\cdot$ Recruitment $\cdot$ Settlement $\cdot$ Abalone Urchins

\section{INTRODUCTION}

The process of recruitment plays a critical role in the structure and dynamics of populations and communities of benthic marine organisms (Thorson 1966, reviewed by Underwood \& Fairweather 1989, Caley et al. 1996). The larval stages of marine organisms, therefore, reflect a critical period in the life cycle, and factors that influence the supply of larvae can play an important role in the regulation of benthic marine populations and communities (Thorson 1950, Gaines et al.
1985). Despite the importance of larval stages, there is still relatively little known about the factors which influence larval mortality in the plankton (Rumrill 1990). Additionally, there is increasing evidence that stresses experienced by larvae in the plankton may influence their ability to metamorphose and perform well as juveniles, with consequential effects on patterns of recruitment (reviewed by Pechenik et al. 1998).

One potential source of stress in the planktonic environment is terrestrially derived runoff. Terrestrially 
derived runoff may have complex direct and indirect effects on marine populations and communities due to both its chemical (e.g. organic pollutants, nutrients, reduced salinity) and physical (e.g. sediments, particulates) properties (Gillanders \& Kingsford 2002). A number of studies have examined the effects of various toxicants or effluents on larval stages (for invertebrates: reviewed by Pechenik 1987, for fish: reviewed by Weis \& Weis 1989, Kingsford \& Gray 1996). For benthic organisms, there is also a well developed literature (especially for corals and seaweeds) examining the effects of accumulated sediment on post-settlement stages by scour/abrasion, the smothering/burial of organisms themselves, or the burial of preferred settlement substrates prohibiting successful settlement (for corals, reviewed by Rogers 1990; for rocky coast organisms, reviewed by Airoldi 2003), and on effects of suspended sediment on adult stages (reviewed by Moore 1977). Finally, there is also a large body of literature on the effects of settled and suspended sediment on freshwater and estuarine invertebrates, plants, fish and other vertebrates (e.g. reviewed by Cordone \& Kelley 1961, Newcombe \& MacDonald 1991, Gillanders \& Kingsford 2002).

Early life stages are particularly vulnerable to toxicants and other stressors (Moore 1977, Pechenik 1987). Despite the commonality and importance of pelagic larval stages in the life cycles of benthic marine invertebrates, to date few published studies have examined the effects of suspended sediments in the water column on larval stages. As exceptions, Davis (1960), and Davis \& Hidu (1969), subjected bivalve eggs and larvae to a variety of concentrations of different particulates (including silt, clay, chalk and Fuller's earth). The only other published study we were able to find examining marine invertebrate larvae and suspended sediment is that of Gilmour (1999), who examined the effects of suspended sediment from dredge operations on fertilisation, survival and settlement of a scleractinian coral. From the freshwater literature this appears true as well, as most published studies on effects of suspended sediments on invertebrates that we found were on benthic organisms or life stages (except see McCabe \& O'Brien 1983).

Sedimentation in coastal areas is globally common and increasing due to a variety of anthropogenic activities including agriculture, construction, deforestation, and industrial and domestic discharges (reviewed by Airoldi 2003, Thrush et al. 2004). Larvae developing in coastal waters are therefore increasingly likely to be exposed to some level of suspended sediment during some portion of their development. Especially prone are those larvae developing in bays or harbours where circulation may be restricted, and anthropogenic sources of sedimentation and runoff common.
In temperate rocky habitats around the world, abalone and urchins are ecologically and economically important species. Both groups are often common and abundant subtidal macrograzers, and consequently may exert a strong influence on community structure (Shepherd 1973, Lawrence 1975, Andrew 1988, Underwood et al. 1991, Karpov et al. 2001). In New Zealand (as elsewhere), abalone and urchins are also harvested commercially and in addition, have strong cultural significance for indigenous Māori communities. Thus, factors that may influence the recruitment of these species have the potential for carryover effects on reef biodiversity and dynamics as well as commercial and domestic fishery management.

The effects of suspended sediment may vary for the larvae of these 2 groups because of their very different larval characteristics. Typical of many urchin species, the common New Zealand urchin Evechinus chloroticus has relatively long lived ( 20 to 40 d) feeding echinopluteus larvae, with 4 pairs of long ciliated arms (Mortensen 1921, Walker 1984, Lamare \& Barker 1999). In contrast, the common New Zealand abalone, Haliotis iris, similar to other abalone species, has a shorter lived ( 3 to $10 \mathrm{~d}$ ), nonfeeding veliger larvae whose soft tissues are encased in a protective shell (or protoconch), except for the ciliated velum, which is extended for swimming (Ino 1952, Tong 1982, Moss \& Tong 1992). In this study, we examine how both chronic and acute exposures to realistic loads of suspended sediment affect the larval development, growth, survival and settlement success of these 2 important species.

\section{MATERIALS AND METHODS}

Suspended sediment loads. We quantified ambient suspended sediment loads from 201 samples of surface water collected at the mouth of the Hutt River in Wellington Harbour, New Zealand $\left(41^{\circ} 14.9^{\prime} \mathrm{S}\right.$, $174^{\circ} 54.0^{\prime}$ E). Samples were collected after rain events on 5 May 2003 ( 2 d subsequent to 3 d heavy rain; first large storm event of winter), 13 June 2003 (3 d subsequent to $2 \mathrm{~d}$ heavy rain), 14 August 2003 (1.5 d subsequent to $2.5 \mathrm{~d}$ moderate rain) and 22 August 2003 (immediately following $2.5 \mathrm{~d}$ heavy rain). Collection was timed in order to characterize typical peak sediment loads to the Wellington Harbour System. Samples were prefiltered through $500 \mu \mathrm{m}$ mesh to remove large particles and debris, and remaining sediments were allowed to settle undisturbed for 14 to $20 \mathrm{~d}$ before $\sim 19.5$ l of water were decanted (subsamples of supernatant sea water were filtered and analyzed to ensure no remaining suspended sediments). Samples from individual buckets ( $\mathrm{n}=5$ to 30,201 buckets) were then 
aggregated, rinsed repeatedly to remove salt, dried to a constant weight at $60^{\circ} \mathrm{C}$, and weighed to calculate ambient sediment per liter of seawater. Subsamples of the dried sediment collected on 5 May 2003 were analysed for grain size and metal toxicants.

Experimental design. We explored the effects of suspended sediments on the development, survival, and settlement of larval urchins and abalone using suspended sediment concentrations calculated from 5 May 2003 sampling and applied to the following treatments: $0 \times$ Ambient (i.e. $0.2 \mu \mathrm{m}$ filtered sea water with no added sediment), $0.5 \times$ Ambient, $1 \times$ Ambient, and $2 \times$ Ambient. These concentrations of suspended sediments were maintained for the duration of the experiments to explore the effects of chronic exposure on larval traits and demographic rates. We examined the effects of acute exposure with additional treatments of $2 \times$ Ambient sediment concentrations administered 'Early' in development (2 to $8 \mathrm{~d}$ postfertilization for urchins; 1 to $3 \mathrm{~d}$ for abalone) or 'Late' in development (14 to $20 \mathrm{~d}$ postfertilization for urchins; 3 to $6 \mathrm{~d}$ for abalone). All sediment treatments were constructed from suspended sediments collected from Wellington Harbour on 5 May 2003, subsequently dehydrated, and autoclaved (to remove biological contaminants).

We reared larval urchins and abalone at Victoria University of Wellington's Island Bay Marine Laboratory (IBML) using a system of continuously stirred replicate jars (described in Strathmann 1987). Each jar contained 21 of $0.2 \mu \mathrm{m}$ filtered seawater, a sediment treatment ( $\mathrm{n}=3$ jars per treatment), and larvae at relatively low initial densities of either 300 abalone $1^{-1}$ or 150 urchins $\mathrm{l}^{-1}$. Jars were immersed in a near constant temperature water bath maintained at $\sim 17.6^{\circ} \mathrm{C}$ (range: $14.84-19.81^{\circ} \mathrm{C}$ ) for urchins and $\sim 12.8^{\circ} \mathrm{C}$ (range: $12.47-13.31^{\circ} \mathrm{C}$ ) for abalone. Abalone larvae were acquired from the National Institute for Water and Atmospheric Research Mahanga Bay Aquaculture Research Facility within $2 \mathrm{~h}$ of spawning (15 August 2003; product of multiple parents), and were reared to settlement $\sim 9$ d later. Urchin larvae were the offspring of a single spawning pair (induced to spawn at IBML on 13 January 2004 by injecting 1 to $3 \mathrm{ml} 0.5 \mathrm{M} \mathrm{KCl}$ ), and were reared to settlement $\sim 25 \mathrm{~d}$ later. Water changes were conducted at 2 to 3 d intervals for both species. Urchin larvae were fed 8000 cells $\mathrm{ml}^{-1}$ of Isochrysis galbana at each water change (abalone larvae do not feed during larval development).

Response variables and data analyses: Larval growth and development: To explore the effect of suspended sediments on patterns of larval growth and development we subsampled and measured individual larvae at each water change. Urchins were heterogeneous in development rates/stages within and among jars, and we limited our analyses of morphometric measurements of urchins to 6-armed plutei sampled on 21 January 2004 (7 d postfertilization) and 8-armed plutei sampled on 27 January 2004 (13 d postfertilization). We examined individual larvae (3 to 6 jar $^{-1}$ ) under a microscope (100 to $200 \times$ magnification) to estimate: (1) maximum midbody length (ML); (2) mean postoral (PO) arm length (average of $\mathrm{R}$ and $\mathrm{L}$ arms); and (3) mean postdorsal (PD) arm length (average of $\mathrm{R}$ and $\mathrm{L}$ arms). For abalone veligers we measured: (1) maximum protoconch length; (2) maximum protoconch width; and (3) aperture diameter, all estimated for 7 to 10 individuals per jar subsampled 5 to $6 \mathrm{~d}$ postfertilization. These developmental stages and morphometric measurements follow Lamare \& Barker (1999), and Sewell et al. (2004).

All morphometric measurements were analysed separately using nested ANOVAs (main effect: sediment concentration). Jar effect was nested within sediment, and individual larvae subsampled from each jar were the residuals (Proc GLM, SAS v8.02). Response variables (i.e. measurements of individual larvae) were $\log _{10}$ transformed as necessary and all variables met ANOVA assumptions after transformation.

Stage specific larval mortality rates: To explore the effect of suspended sediments on temporal patterns of larval mortality, we counted the number of remaining live larvae at $6 \mathrm{~d}$ intervals for urchins and 2 to $3 \mathrm{~d}$ intervals for abalone. From these counts, we estimated an average per capita mortality rate (i.e. daily probability of mortality for an individual larva) for each replicate jar in each time interval. $\log _{10}$ transformed per capita mortality rates were analysed using Repeated Measures ANOVAs (Proc GLM, SAS v8.02) to test for (1) overall effects of sediment regime on per capita mortality rates, (2) variation in mortality rates through time (i.e. as a function of larval developmental stage), and (3) an interaction between sediment regime and developmental stage (indicating stage specific responses and/or effects of acute exposures). For each species, we conducted separate analyses to explore the effects of 'sediment concentration' (either $0,0.5,1$ or $2 \times$ Ambient suspended sediment concentrations) and 'timing of exposure' (either $2 \times$ chronic exposure, $2 \times$ early acute, or $2 \times$ late acute exposure). One replicate jar of the $1 \times$ Ambient treatment in the urchin experiment became contaminated by protistans early in the experiment, and another jar (a replicate of the $0 \times$ Ambient treatment) was spilled during the final counting of larvae at the termination of the experiment (previous counts of live urchin larvae in this jar closely tracked the other control jars). Both jars were excluded from RM ANOVA and subsequent analyses.

Cumulative effects on recruitment: To explore the cumulative effects of suspended sediments on patterns 
of recruitment of urchins and abalone, we estimated: (1) proportional mortality of larvae by the end of larval development (competency was reached 20 and $9 \mathrm{~d}$ postfertilization respectively); and (2) proportion of successful settlement. Because urchins appeared to require no specific cue to trigger settlement/metamorphosis, 'successful settlement' was estimated as the proportion of surviving individuals (larvae + metamorphs) in each jar 25 d postfertilization that had successfully metamorphosed into benthic juveniles. Abalone require cues to trigger settlement and metamorphosis. Consequently, larvae from replicate jars of $0 \times$ Ambient, $1 \times$ Ambient, $2 \times$ Early and $2 \times$ Late treatments were pooled within treatments and provided with a cue to induce settlement (low larval survival required pooling and prevented inclusion of a $2 \times$ chronic exposure). Twenty-five larvae from each treatment were allocated to replicate glass dishes $(\mathrm{n}=3$ ) containing $150 \mathrm{ml} 0.2 \mu \mathrm{m}$ filtered sea water and small cobbles covered with nongeniculate coralline algae (Lithothamnion spp., a known settlement cue for abalone). We estimated successful settlement of abalone for each glass dish as the product of the proportion settlers per dish and the proportion surviving larvae (i.e. mean proportion of surviving individuals 9 d postfertilization, averaged across replicate jars within a treatment).

We analysed patterns of cumulative mortality and successful settlement separately, within and among species, and as a function of sediment regime using factorial 2-way ANOVA (main effects 'sediment regime' and 'species'; Proc GLM, SAS v8.02). Response variables were square root-arcsine transformed to meet ANOVA assumptions.

\section{RESULTS}

\section{Suspended sediment loads}

We estimated the ambient suspended sediment concentration flowing from the mouth of the Hutt River on 5 May 2003 to be $0.03677 \mathrm{~g} \mathrm{l}^{-1}$. Based upon this estimate, our $0.5 \times$ Ambient sediment treatment was com-
Table 1. Effects of suspended sediment concentration on growth and developmental traits of urchin Evechinus chloroticus and abalone Haliotis iris larvae. Example ANOVA tables show nested models used to evaluate sources of variation: for E. chloroticus, in midbody length of 6-armed pluteus larvae; and for abalone veligers, in protoconch length ( $6 \mathrm{~d}$ postfertilisation). Because additional p-values (in parentheses) of main effects (sediment concentration) and nested effects (jar within sediment concentration) are given. Significant effects ( $p<$ $0.05)$ are given in bold. Where required, response variables have been $\log _{10}$ transformed to meet ANOVA assumptions. F-ratios are calculated from Type III SS

\begin{tabular}{|c|c|c|c|c|}
\hline Source of variation & df & MS & $F$ & $\mathrm{p}$ \\
\hline \multicolumn{5}{|l|}{ E. chloroticus } \\
\hline Sediment concentration & 3 & 0.00128 & 1.33 & 0.28 \\
\hline Jar (Sediment concentration) & 7 & 0.00083 & 0.86 & 0.54 \\
\hline Residual & 49 & 0.00096 & & \\
\hline \multicolumn{5}{|l|}{ H. iris } \\
\hline Sediment concentration & 3 & 162.50 & 3.24 & 0.03 \\
\hline Jar (Sediment concentration) & 8 & 27.46 & 0.55 & 0.82 \\
\hline Residual & 108 & 0.00096 & & \\
\hline Response variable & & $\begin{array}{c}\text { Sediment } \\
\text { concentration } \\
F(\mathrm{p})\end{array}$ & \multicolumn{2}{|c|}{$\begin{array}{c}\text { Jar (Sediment } \\
\text { concentration) } \\
F(\mathrm{p})\end{array}$} \\
\hline \multicolumn{5}{|l|}{ Effects on larval E. chloroticus } \\
\hline \multicolumn{5}{|l|}{ 6-armed pluteus larvae } \\
\hline Mid-body length (ML) & & $1.33(0.28)$ & \multicolumn{2}{|c|}{$0.86(0.54)$} \\
\hline Mean postoral arm length (PO) & & $8.86(<0.0001)$ & \multicolumn{2}{|c|}{$1.10(0.38)$} \\
\hline Mean postdorsal arm length (PD & & $1.99(0.13)$ & \multicolumn{2}{|c|}{$0.50(0.83)$} \\
\hline \multicolumn{5}{|l|}{ 8-armed pluteus larvae } \\
\hline Mid-body length (ML) & & $2.40(0.08)$ & \multicolumn{2}{|c|}{$0.96(0.47)$} \\
\hline Mean postoral arm length (PO) & & $1.32(0.28)$ & \multicolumn{2}{|c|}{$1.45(0.21)$} \\
\hline Mean postdorsal arm length (PD & & $2.52(0.07)$ & \multicolumn{2}{|c|}{$2.44(0.03)$} \\
\hline \multicolumn{5}{|l|}{ Effects on larval $H$. iris } \\
\hline Protoconch length & & $3.24(0.03)$ & \multicolumn{2}{|c|}{$0.55(0.82)$} \\
\hline Protoconch width & & $0.81(0.49)$ & \multicolumn{2}{|c|}{$2.64(0.01)$} \\
\hline Aperture diameter & & $0.42(0.74)$ & \multicolumn{2}{|c|}{$1.76(0.09)$} \\
\hline
\end{tabular}

prised of $0.01839 \mathrm{~g} \mathrm{l}^{-1}$, the $1 \times$ Ambient treatment of $0.03677 \mathrm{~g} \mathrm{l}^{-1}$, and the $2 \times$ Ambient treatment of $0.07354 \mathrm{~g} \mathrm{l}^{-1}$. Concentrations of suspended sediments in additional water samples taken from Wellington Harbour near the mouth of the Hutt River $\left(0.00614 \mathrm{~g} \mathrm{l}^{-1}\right.$ on 13 June 2003, $0.00688 \mathrm{~g} \mathrm{l}^{-1}$ on 14 August 2003, and $0.1468 \mathrm{~g} \mathrm{l}^{-1}$ on 22 August 2003) suggest our experimental treatments are well within the range of probable concentrations encountered by wild larvae developing in the vicinity of the inner Harbour following large rain events. Although there is often a seasonal pattern to average rainfall in much of New Zealand, rainfall in the Wellington region is relatively high throughout the year, and large rain events can happen any time of year (Kidson 1950, Goulter 1984). Moreover, the turbidity plume from the Hutt River after a large rain event often extends out across much of the 
inner harbour for up to several days (Maxwell 1956, N. Phillips pers. obs.)

The sediment was composed of $10 \%$ sand (500 to $60 \mu \mathrm{m}$ diameter), $40 \%$ silt (60 to $2 \mu \mathrm{m}$ diameter) and $60 \%$ clay $(\leq 2 \mu \mathrm{m}$ diameter). In total, $80 \%$ of the particles were $<10 \mu \mathrm{m}$, nearly $40 \%<1 \mu \mathrm{m}$. The elemental composition of this sediment was very similar to other local sources of uncontaminated rocks and sediments (e.g. $\mathrm{Cd}$ and $\mathrm{Sn}$ at undetectable levels, $\mathrm{Ni}, \mathrm{Cr}, \mathrm{Cu}, \mathrm{Zn}$ and $\mathrm{Pb}$ at very low levels, J. Patterson pers. comm.).

\section{Larval growth and development}

Exposure to sediments appeared to affect some attributes of larval growth and morphology of early developmental stages of urchin and abalone larvae (Table 1). For Evechinus chloroticus, 6-armed pluteus larvae exposed to sediments of any concentration had significantly reduced $\mathrm{PO}$ arm lengths relative to larvae reared without sediments. 6-armed pluteus larvae reared without sediments also showed a nonsignificant trend $(\mathrm{p}=0.13)$ of larger PD arm lengths. 8-armed pluteus larvae reared without sediments showed a nonsignificant trend $(\mathrm{p}=0.08)$ of larger ML. 8-armed pluteus larvae reared in $2 \times$ ambient sediments showed a nonsignificant trend $(\mathrm{p}=$ 0.07) of larger PD arm lengths, although the responses among jars were heterogeneous (illustrated by a significant jar-within-sediment effect). Abalone veligers reared in $2 \times$ ambient sediments had significantly longer protoconchs than larvae reared in lower concentrations (including no sediments). The protoconch widths of veligers were heterogeneous among jars (a significant jar-within-sediment effect), particularly for $0 \times, 0.5 \times$ and $1 \times$ concentrations; in contrast, protoconch widths among jars in the $2 \times$ concentration were relatively homogeneous.

\section{Stage specific larval mortality rates}

Sediment regime (concentration and timing of exposure) affected per capita mortality rates of both urchin and abalone larvae (Table 2). For Evechinus chloroticus larvae that were chronically exposed to suspended sediments in different concentrations, those reared in $2 \times$ ambient concentrations had consistently higher rates of daily per capita mortality (Fig. 1A). Larvae reared in $1 \times$ and $0.5 \times$ concentrations had intermediate per capita mortality rates, and those reared without sediments had the lowest mortality rates. For all treatments, mortality rates generally decreased with stage of development (supported by a significant stage-of-development effect in Table 2A and declines in mortality with days postfertilization in Fig. 1A), although per capita mortality also showed a moderate increase in the third quarter of larval development. Under chronic exposures, the responses of $E$. chloroticus larvae reared in different concentrations of suspended sediments were consistent through time (i.e. the sediment $\times$ stage interaction was not significant).

The timing of exposure to suspended sediments had significant effects on per capita mortality rates for Evechinus chloroticus larvae (Table 2B). E. chloroticus larvae exposed to $2 \times$ ambient concentrations early in development experienced high rates of mortality (similar to mortality rates of larvae exposed chronically to $2 \times$ concentrations), and upon removal of sediments

Table 2. Repeated measures ANOVA of stage-specific per capita mortality rates. Separate RM ANOVAs to test effects of $(A, C)$ suspended sediment concentration and $(\mathrm{B}, \mathrm{D})$ timing of exposure on per capita mortality of $(\mathrm{A}, \mathrm{B})$ urchin Evechicus chloroticus and $(\mathrm{C}, \mathrm{D})$ abalone Haliotis iris larvae. Significant effects $(\mathrm{p}<$ 0.05) are given in bold. Response variables have been $\log _{10}$-transformed to meet ANOVA assumprions. F-ratios are calculated from Type III SS

\begin{tabular}{|c|c|c|c|c|}
\hline Source & $\mathrm{df}$ & MS & $F$ & $\mathrm{p}$ \\
\hline \multicolumn{5}{|c|}{ (A) E. chloroticus (chronic exposure to concentration gradient) } \\
\hline Sediment concentration & 3 & 0.338 & 26.03 & 0.008 \\
\hline Replicate(sediment) & 6 & 0.013 & & \\
\hline Stage of development & 3 & 0.193 & 10.63 & 0.003 \\
\hline Sediment $\times$ Stage & 9 & 0.023 & 1.24 & 0.330 \\
\hline Replicate $($ sediment $) \times$ Stage & 18 & 0.018 & & \\
\hline \multicolumn{5}{|c|}{$\begin{array}{l}\text { (B) E. chloroticus (acute exposure early- or late in development, } \\
\text { vs. chronic exposure) }\end{array}$} \\
\hline Sediment timing & 2 & 0.349 & 10.60 & 0.011 \\
\hline Replicate(sediment) & 6 & 0.033 & & \\
\hline Stage of development & 3 & 0.199 & 11.53 & 0.002 \\
\hline Sediment $\times$ Stage & 6 & 0.068 & 3.93 & 0.011 \\
\hline Replicate $($ sediment $) \times$ Stage & 18 & 0.017 & & \\
\hline \multicolumn{5}{|c|}{ (C) $H$. iris (chronic exposure to concentration gradient) } \\
\hline Sediment concentration & 3 & 0.399 & 6.21 & 0.017 \\
\hline Replicate(sediment) & 8 & 0.064 & & \\
\hline Stage of development & 2 & 0.0329 & 10.57 & 0.001 \\
\hline Sediment $\times$ Stage & 6 & 0.040 & 1.27 & 0.324 \\
\hline Replicate $($ sediment $) \times$ Stage & 16 & 0.031 & & \\
\hline \multicolumn{5}{|c|}{$\begin{array}{l}\text { (D) H. iris (acute exposure early- or late in development, } \\
\text { vs. chronic exposure) }\end{array}$} \\
\hline Sediment timing & 2 & 0.312 & 6.06 & 0.036 \\
\hline Replicate(sediment) & 6 & 0.0514 & & \\
\hline Stage of development & 2 & 0.233 & 3.39 & 0.068 \\
\hline Sediment $\times$ Stage & 4 & 0.129 & 1.87 & 0.180 \\
\hline Replicate $($ sediment $) \times$ Stage & 12 & 0.069 & & \\
\hline
\end{tabular}




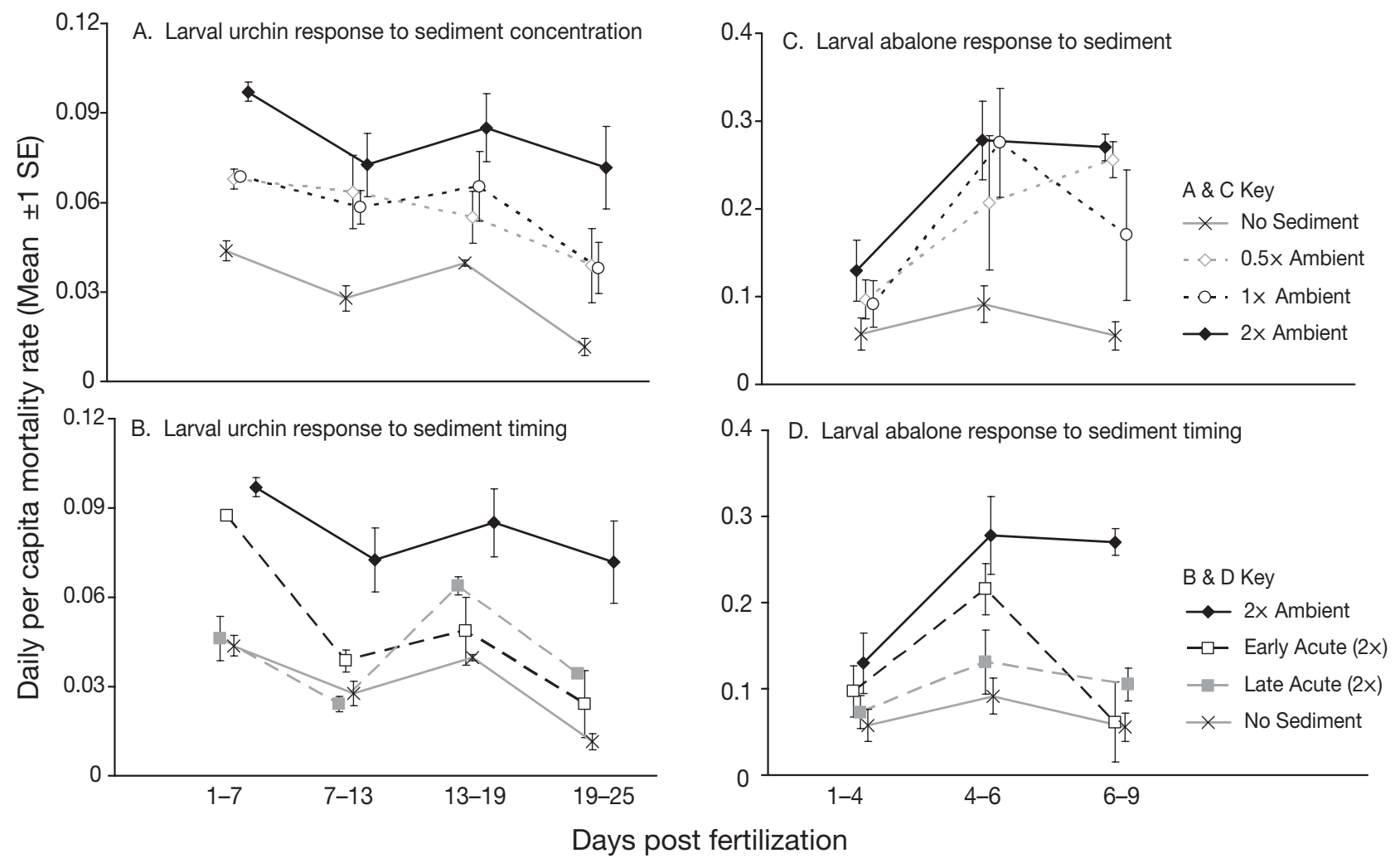

Fig. 1. Effects of suspended sediment regime (concentration and timing of exposure) on daily probabilities of mortality for larval (A, B) urchins Evechinus chloroticus; and (C, D) abalone Haliotis iris. Per capita mortality rates are calculated as fractional losses over given ranges of days postfertilization, effects of suspended sediment concentration are given in panels A and C, effects of timing of exposure are given in panels B and D. Relative positions of points have been shifted horizontally to facilitate presentation of SE. Note different scales on $y$-axes

mortality rates dropped to levels consistent with larvae reared in the absence of suspended sediments (Fig. 1B). Similarly, E. chloroticus larvae exposed to $2 \times$ ambient concentrations late in development experienced elevated mortality rates only during the period of exposure. Again, RM ANOVA suggested that per capita mortality rates of urchin larvae varied with stage of development, and when timing of exposure to sediments was manipulated, the analysis indicated a significant sediment $\times$ stage interaction (Table $2 \mathrm{~B}$ ).

For abalone larvae that were chronically exposed to suspended sediments in different concentrations per capita mortality rates differed among treatments, but only after Day 4 of development (Table 2C, Fig. 1C). Daily per capita mortality rates in the first third of larval development were constant among treatments, and relatively low. In subsequent stages of development, exposure to sediments in any concentration resulted in high rates of mortality relative to larvae reared in the absence of suspended sediments (supported by a significant stage-of-development effect, Table 2C, cf. Fig. 2C).

The timing of exposure to suspended sediments had significant effects on per capita mortality rates of abalone larvae (Table 2D). In contrast to the relatively immediate effects of acute exposure to sediments observed for Evechinus chloroticus, larval Haliotis iris showed a delayed response to early acute exposure to $2 \times$ ambient sediment concentrations (elevated mortality in the middle third of development), and a comparatively weak response to acute exposure to suspended sediments late in development (Fig. 2D).

\section{Cumulative effects on settlement}

Cumulative mortality of larval urchins and abalone varied significantly among sediment treatments but not among species (Table 3A, Fig. 2A). The 2-way ANOVA suggests that the overall response of urchin and abalone larvae to sediment treatments is similar (i.e. interaction between species and treatment was not significant; Table 3A), however Fig. 2A suggests Haliotis iris larvae are strongly adversely affected by chronic exposure to sediments regardless of concentration while Evechinus chloroticus larvae show a more graded response to increasing sediment concentrations. H. iris and E. chloroticus also show qualita- 
tively different trends for early versus late acute exposure to suspended sediments. $H$. iris larvae exposed to sediments early in their development suffered $13 \%$ greater losses than $H$. iris larvae exposed later in their development. In contrast, E. chloroticus larvae exposed to the same concentrations of sediments later in their development had similar losses to those larvae exposed earlier in development.

Of the larvae that successfully survived to competency, urchin larvae were twice as likely to settle as abalone larvae (Fig. 2B, Table 3B, significant species effect). Sediment treatment did not appear to affect settlement success of surviving larvae (Table 3B), nor did the 2 species show differential responses to sediment treatments (i.e. interaction between species and treatment was not significant; Table 3B).

\section{DISCUSSION}

Exposure to suspended sediments primarily caused dramatic increases in larval mortality for both abalone and urchins, and did not appear to have strong effects on the ability of surviving larvae to successfully settle and metamorphose. There were, however, some unexpected effects of sediment on larval morphology for

\section{A. Larval mortality}
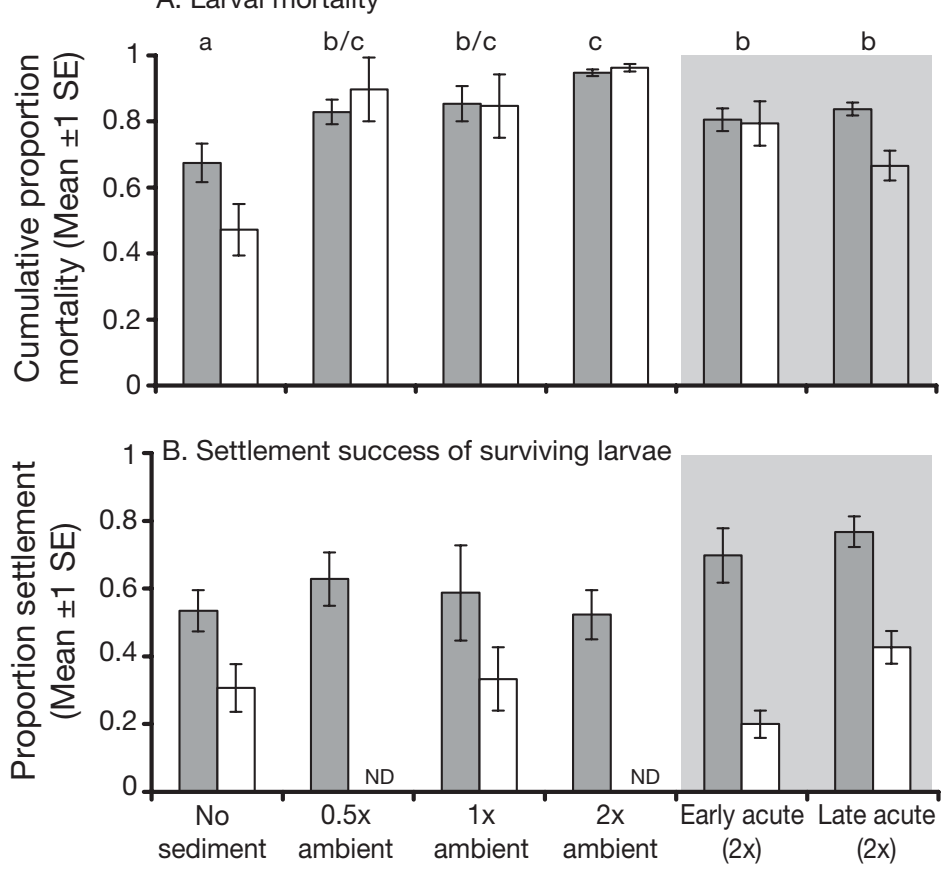

Fig. 2. Effects of suspended sediment regime (concentration and timing of exposure) on (A) cumulative larval mortality and (B) proportion of larval survivors that successfully settled, for larval urchins (Evechinus chloroticus, dark grey bars) and abalone (Haliotis iris, white bars). Light grey regions denote acute exposure to $2 \times$ Ambient sediments, administered early or late in development. Post hoc Tukey groupings are given as letters above sets of bars; ND: no data
Table 3. Two-way ANOVA of the cumulative effects of sediment regime on (A) larval mortality and (B) successful settlement of surviving larvae. (A) Sediment regime has 6 levels corresponding to manipulations of suspended sediment concentration and timing of exposure (see Fig. 2A). (B) Sediment regime has 4 levels (treatments for which data were missing for abalone were omitted; see Fig. 2B). In both analyses, species has 2 levels: urchins (Evechinus chloroticus) and abalone (Haliotis iris). Significant effects $(p<0.05)$ are given in bold. Response variables square-root arc sine transformed to meet ANOVA assumptions. F-ratios are calculated from Type III SS

\begin{tabular}{|lcccc|}
\hline Source of variation & df & MS & $F$ & $p$ \\
\hline (A) Larval mortality & & & & \\
Sediment regime & 5 & 0.167 & 9.67 & $<\mathbf{0 . 0 0 0 1}$ \\
Species & 1 & 0.011 & 0.65 & 0.47 \\
Sediment $\times$ Species & 5 & 0.025 & 1.46 & 0.24 \\
(B) Settlement success & & & & \\
Sediment regime & 3 & 0.042 & 2.52 & 0.1002 \\
Species & 1 & 0.654 & 39.37 & $<\mathbf{0 . 0 0 0 1}$ \\
Sediment $\times$ Species & 3 & 0.025 & 1.48 & 0.26 \\
\hline
\end{tabular}

both species. For urchin pluteus larvae at the 6-armed stage, larvae exposed to sediment had shorter PO arms than those raised without sediment; similarly, there was a trend for larvae raised without sediment to have longer PD arms than larvae raised in sediment. At the 8-armed stage, however, the trend was in the opposite direction, whereby larvae reared in the highest sediment treatment tended to have longer PD arm lengths, (although the responses among jars were heterogeneous). At the 8armed stage, there was also a trend for larvae raised without exposure to sediment to have a longer body length. Similar to the trend for the 8-armed urchin larvae, protoconchs of abalone larvae raised in the highest sediment treatment were significantly longer than those raised in lower concentrations (or no sediment).

Several species of temperate echinoderm larvae exhibit developmental plasticity in which larvae raised in low food concentrations grow longer arms relative to those raised in higher food concentrations (e.g. Boidron-Metairon 1988, Strathmann et al. 1992, Fenaux et al. 1994). Because the arms of the pluteus larvae are ciliated, and are the means by which they capture food particles, larvae in low food environments increase the length of the ciliated band by increasing their arm length, and thereby increase their opportunity to capture food (Strathmann et al. 1992). Sewell et al. (2004) found that Evechinus chloroticus larvae also exhibit this sort of developmental plasticity, but only up to the 4 -armed stage. Larvae in low food concentrations failed to develop past that 
stage altogether. In the current experiment, we found that at the 6-armed stage, larvae exposed to sediment had shorter arms than those not exposed to sediment. In the above framework, this might suggest that sediment in fact increased the ability of larvae to feed, perhaps by the adherence of food particles to the sediment. However, since Sewell et al. (2004) did not find evidence of developmental plasticity in E. chloroticus at later developmental stages, this hypothesis is difficult to evaluate.

This hypothesis also does not hold for the 8-armed pluteus larvae, where the trend appeared to be in the opposite direction. Different explanations may be required to account for patterns observed for later stages of urchin larvae, as well as the abalone veligers. In both cases the larvae in the higher sediment treatments were generally larger in one or more dimension. Due to the high rates of mortality occurring, one possibility is that high sediment treatments imposed size selective mortality operating disproportionately on smaller larvae, skewing the resultant distribution of survivors to larger sizes. This hypothesis may be further supported by the fact that the protoconch widths of abalone veligers were heterogeneous among jars for the lower sediment concentrations and the no sediment treatment. In contrast, protoconch widths among jars in the highest sediment concentration were relatively homogeneous, suggesting the operation of size selective mortality that reduces variance in sizes of survivors.

In contrast to the effects on morphological traits, effects of sediment exposure on stage specific mortality rates were much more pronounced, and generally consistent with the few other published studies we were able to locate. For example, Gilmour (1999) found that suspended sediments in similar concentrations to this study $\left(0.100\right.$ and $0.050 \mathrm{~g} \mathrm{l}^{-1}$, conservatively based on suspended sediment loads in Coral Bay, Western Australia following dredging operations) significantly reduced fertilization and larval survival for the coral Acropora digitifera, but did not affect development. Unlike this study, Gilmour (1999) also found that exposure to sediment reduced settlement success for the coral as well; however, this was likely due to high levels of sediment settled on the substrate in that experiment.

Davis (1960) and Davis \& Hidu (1969) investigated effects of silt, kaolin clay, and other particulates on bivalve larvae and found differential effects depending on particle size. Davis (1960) found no mortality of clam Mercenaria mercenaria larvae in any concentration of silt (in the range 0.125 to $4 \mathrm{~g} \mathrm{l}^{-1}$ ), and little effect on growth at $<1 \mathrm{~g} \mathrm{l}^{-1}$. However, larval mortality was $50 \%$ in concentrations of $0.5 \mathrm{~g} \mathrm{l}^{-1}$ of clay, and exceeded $90 \%$ in higher concentrations. For American oysters Crassostrea virginica, by comparison, silt was more harmful than clay for larval survival, and at a threshold concentration of $0.75 \mathrm{~g} \mathrm{l}^{-1}$ (Davis \& Hidu 1969). Finally, Davis \& Hidu also found that it was primarily the smallest particles that affected survival for both clams and the American oyster, which suffered severe mortality (at concentrations of 0.250 and $0.125 \mathrm{~g} \mathrm{l}^{-1}$, respectively) in the presence of particles smaller than $5 \mu \mathrm{m}$. Larger particles, even in relatively high concentrations, had little effect on survival of either clam or oyster larvae. Overall, bivalve larvae in those experiments appeared to tolerate much higher concentrations of particulates than the abalone and urchin larvae in this study, however there were substantial species specific differences among the 3 bivalves examined.

In the current study, urchin larvae appeared to tolerate exposure to sediment better than abalone larvae. The increase in cumulative mortality for sediment treatments compared to controls was less dramatic for urchins than abalone, and total mortality for urchins decreased in lower sediment concentrations, whereas abalone larvae experienced similar high losses at all concentrations examined. For both species, short term exposure to high sediment loads was generally worse if exposure occurred early in larval life compared to later in larval life. Although urchin larvae had a stronger response than abalone to acute exposure to sediment later in larval life, they recovered more quickly (in terms of mortality rates) from short term exposure to sediment than abalone. For urchins, sediment effects subsided immediately after sediment removal. This is similar to the findings of Davis (1960), who reported that clam larvae from eggs that had developed for $2 \mathrm{~d}$ in high concentrations of suspended material were able to survive and metamorphose, if returned to normal seawater. In contrast, acute early exposure to high concentrations of sediments continued to strongly affect mortality rates of abalone larvae well after all sediments were removed, resulting in greater cumulative mortality in this treatment compared to the late acute treatment. These results suggest that for natural cohorts of larvae, which are probably more likely to encounter plumes of suspended sediment transiently rather than throughout the entirety of their larval duration, early stage larvae are more vulnerable to this exposure than later stage larvae. These results also suggest that even transient exposure to a turbidity plume of high sediment load may be a substantial cause of larval mortality, especially for abalone larvae.

The actual mechanism by which exposure to sediment increased mortality in both species cannot be determined from this study. The apparent greater sensitivity of abalone larvae to sediment exposure compared to urchin larvae was a surprising result. Abalone larvae have a protective shell covering from which 
only the velum protrudes, whereas larval urchin have no protective covering, and have a seemingly more delicate structure (with multiple long arms with ciliated bands). Unlike abalone larvae, urchins actively feed during development, and may therefore have been vulnerable to sediment particles interfering with feeding. We found no evidence to support this hypothesis however. Another possibility is that our use of autoclaved sediments inadvertently increased the bacterial load in the jars (due to the potentially increased organic content of the sediment after autoclaving), and the abalone larvae could have been differentially vulnerable to any bacterial contamination that may have occurred. It could be argued that the relatively low mortality rates of abalone larvae in sediment treatments in the first $4 \mathrm{~d}$ do not support this hypothesis, however additional work is required to address it specifically, and to clarify mechanisms underlying differential patterns of mortality for these 2 species.

This study is among the first to explicitly examine the effects of suspended sediment on the larval development, survival and settlement success of 2 common and important reef species. The results suggest that even relatively short duration exposure to high sediment loads may cause substantial larval mortality in these 2 species, thus reducing the supply of larvae available for recruitment. Future research will be critical in determining the cumulative effects of terrestrial runoff on natural populations of coastal larvae because in addition to suspended sediment, other factors (e.g. reduced salinity, increased toxicants) are likely to be important and may act synergistically and in species specific ways. Because of the worldwide increases in terrestrial runoff and coastal sedimentation (Airoldi 2003, Thrush et al. 2004), differential effects of suspended sediments among species (and their consequences for patterns of recruitment) may dramatically alter community structure and ecosystem function.

Acknowledgements. We thank L. Liggins, S. Geange, J. Long, R. Williamson, and J. Allen for their assistance with laboratory and field work; J. Carter and J. Patterson for help with analysing sediment samples; and G. Moss at NIWA's Mahanga Bay Aquaculture Research Facility for supplying abalone larvae. This research further benefited from useful discussions with A. M. Schwarz and N. Andrew, and was funded by the US National Science Foundation (to N. Phillips: NSF-INT-0202713), the New Zealand Ministry of Fisheries (to NIWA: ZBD2002/06A), and Victoria University of Wellington.

\section{LITERATURE CITED}

Airoldi L (2003) The effects of sedimentation on rocky coast assemblages. Oceanogr Mar Biol Annu Rev 41:161-236

Andrew NL (1988) Ecological aspects of the common sea urchin, Evechinus chlorotictus, in northern New Zealand: a review. NZ J Mar Freshw Res 22:415-426
Boidron-Metairon IF (1988) Morphological plasticity in laboratory-reared echinoplutei of Dendraster excentricus (Eschscholtz) and Lytechinus veriegatus (Lamarck) in response to food conditions. J Exp Mar Biol Ecol 119: $31-41$

Caley MJ, Carr MH, Hixon MA, Huges TP, Jones GP, Menge BA (1996) Recruitment and the local dynamics of open marine populations. Annu Rev Ecol Syst 27:477-500

Cordone AJ, Kelley DW (1961) The influence of inorganic sediment on the aquatic life of streams. Calif Fish Game 47:189-228

Davis HC (1960) Effects of turbidity-producing materials in seawater on eggs and larvae of the clam (Venus (Mercenaria) mercenaria). Biol Bull 118:48-54

Davis HC, Hidu H (1969) Effects of turbidity-producing substances in seawater on eggs and larvae of three general of bivalve mollusks. Veliger 11:316-323

Fenaux L, Strathmann MF, Strathmann RR (1994) Five tests of food-limited growth of larvae in coastal waters by comparisons of rates of development and form of echinoplutei. Limnol Oceanogr 39:84-98

Gaines S, Brown S, Roughgarden J (1985) Spatial variation in larval concentrations as a cause of spatial variation in settlement for the barnacle, Balanus glandula. Oecologia 67: $267-272$

Gillanders BM, Kingsford MJ (2002) Impact of changes in flow of freshwater on estuarine and open coastal habitats and the associated organisms. Oceanogr Mar Biol Annu Rev 40:233-309

Gilmour J (1999) Experimental investigation into the effects of suspended sediment on ferilisation, larval survival and settlerment in a scleractinian coral. Mar Biol 135:451-462

Goulter SW (1984) The climate and weather of the Wellington region. NZ Met Ser Misc Pub 115(16), Wellington

Ino $\mathrm{T}$ (1952) Biological studies of the propagation of the Japanese abalone (genus Haliotis). Bull Tokai Reg Fish Res Lab 5:29-102

Karpov KA, Tegner MJ, Rogers-Bennett L, Kalvass PE, Taniguchi IK (2001) Interactions among red abalones and sea urchins in fished and reserve sites of northern California: implications of competition to management. J Shellfish Res 20:743-753

Kidson E (1950) The elements of New Zealand's climate. In: Garnier BJ (ed) New Zealand weather and climate. Whitcombe \& Tombs, Christchurch, p 45-84

Kingsford MJ, Gray CA (1996) Influence of pollutants and oceanography on abundance and deformities of wid fish larvae. In: Schmitt RJ, Osenberg CW (eds) Detecting ecological impacts: concepts and applications in coastal habitats. Academic Press, San Diego, CA, p 235-255

Lamare MD, Barker MF (1999) In situ estimates of larval development and mortality in the New Zealand sea urchin Evechinus chloroticus (Echinodermata: Echinoidea). Mar Ecol Prog Ser 180:197-211

Lawrence JM (1975) On the relationships between marine plants and sea urchins. Oceanogr Mar Biol Annu Rev 13: 213-286

Maxwell BE (1956) Notes on the diatoms in Wellington Harbour 1953-54. Trans R Soc NZ 84:197-200

McCabe GD, O'Brien WJ (1983) The effects of suspended silt on feeding and reproduction of Daphnia pulex. Am Midl Nat 110:324-337

Moore PG (1977) Inorganic particulate suspensions in the sea and their effects on marine animals. Oceanogr Mar Biol Annu Rev 15:225-363

Mortensen T (1921) Studies of the development and larval forms of echinoderms. GEC Gad, Copenhagen 
Moss GA, Tong LJ (1992) Effect of stage of larval development on the settlement of the abalone, Haliotis iris. NZ J Mar Freshw Res 26:69-73

Newcombe CP, MacDonald DD (1991) Effects of suspended sediments on aquatic ecosystems. Am J Fish Manage 11: 72-82

Pechenik JA (1987) Environmental influences on larval survival and development. In: Giese AC, Pearse JS (eds) Reproduction of marine invertebrates, Vol 9. Blackwell Scientific, Palo Alto, CA, p 551-608

Pechenik JA, Wendt DE, Jarrett JN (1998) Metamorphosis is not a new beginning: larval experience influences juvenile performance. Bioscience 48:901-910

Rogers CS (1990) Responses of coral reefs and reef organisms to sedimentation. Mar Ecol Prog Ser 62:185-202

Rumrill SS (1990) Natural mortality of marine invertebrate larvae. Ophelia 32:163-198

Sewell MA, Cameron MJ, McArdle BH (2004) Developmental platisicity in larval development in the echinometrid sea urchin Evechinus chloroticus with varying food ration. J Exp Mar Biol Ecol 309:219-237

Shepherd SA (1973) Studies on southern Australian abalone (genus Haliotis) 1. The ecology of five sympatric species. Aust J Mar Freshw Res 24:217-257

Strathmann MF (1987) Reproduction and development of the marine invertebrates of the northern Pacific coast, data and methods for the study of eggs, embryos and larvae. University of Washington Press, Seattle, WA

Editorial responsibility: Otto Kinne (Editor-in-Chief), Oldendorf/Luhe, Germany
Strathmann RR, Fenaux L, Strathmann MF (1992) Heterochronic developmental plasticity in larval sea urchins and its implications for evolution of nonfeeding larvae. Evolution 46:972-986

Thorson G (1950) Reproductive and larval ecology of marine bottom invertebrates. Biol Rev 25:1-45

Thorson G (1966) Some factors influencing the recruitment and establishment of marine benthic communities. Neth J Sea Res 3:267-293

Thrush SF, Hewitt JE, Cummings VJ, Ellis JI, Hatton C, Lohrer A, Norkko A (2004) Muddy waters: elevating sediment input to coastal and estuarine habitats. Front Ecol Environ 2:299-306

Tong LJ (1982) The potential for aquaculture of paua in New Zealand. In: Akroyd JM, Murray TE, Taylor JL (eds), Proc of the Paua Fishery Workshop, New Zealand Ministry of Agriculture and Fisheries, Wellington, Fisheries Research Division Occasional Publication 41, p 36-40

Underwood, AJ, Fairweather PG (1989) Supply-side ecology and benthic marine assemblages. Trends Ecol Evol 4:16-20

Underwood AJ, Kingsford MJ, Andrew NL (1991) Patterns in shallow subtidal marine assemblages along the coast of New South Wales. Aust J Ecol 6:231-249

Walker MM (1984) Larval life span, larval settlement, and early growth of Evechinus chloroticus (Valenciennes). NZ J Mar Freshw Res 18:393-397

Weis JS, Weis P (1989) Effects of environmental pollutants on early fish development. Rev Aquat Sci 1:46-73

Submitted: January 6, 2005; Accepted: November 10, 2005

Proofs received from author(s): May 3, 2006 